\title{
Review Literatur: Analisis Determinan Sosio Demografi Kejadian Stunting Pada Balita di Berbagai Negara Berkembang
}

\section{LITERATURE REVIEW: ANALYSIS OF SOCIO DEMOGRAPHYC DETERMINANT ON THE INCIDENCE OF STUNTING AMONG CHILDREN UNDER FIVE YEARS IN VARIOUS DEVELOPING COUNTRIES}

\author{
Rachma Purwanti ${ }^{1 *}$, Desi Nurfita ${ }^{2 *}$ \\ ${ }^{1}$ Departemen Ilmu Gizi, Fakultas Kedokteran, Universitas Diponegoro. \\ Jln Prof. H. Soedarto, SH. Tembalang Semarang \\ ${ }^{2}$ Fakultas Kesehatan Masyarakat, Universitas Ahmad Dahlan. \\ Jl. Prof. Dr. Soepomo, S.H Warungboto Yogyakarta 55164 \\ *email : rachmapurwanti@fk.undip.ac.id \\ *email: desi.nurfita@ikm.uad.ac.id
}

Submitted:09-02-2019, Revised:11-07-2019, Revised:17-08-2019, Accepted: 30-08-2019

\begin{abstract}
UNICEF reported that in 2014 as many as 2/3 of the number of children aged less than five years in low income countries experienced stunting. Stunting is a predictor of the poor quality of human resources and decreasing the productivity of mation in the future. This literature review aims to analyse sociodemographic determinants of the incidence of stunting in children in various developing countries. The design of this study is a literature review with a systematic review method. Articles are traced using several search enginse. The Google Database is the main source in this literature review. The inclusion criteria of the selected articles include: 1) journal/scientific report, 2) presentation in English, 3) Published last 10 years (2008 - 2018), 4) articles using research subject are children $<60$ months old, and, 5) articles with design correlation research There was a positive relationship between recidence and the incidence of stunting ( $p<0,0001 ; p<0,05 ; p<0,01 ; p<0,0001)$. There is a negative relationships between family economic status and the incidence of stunting $(p<0,0001 ; p<0,001 ; p<0,001)$, the education level of mothers with the incidence of stunting $(p<0,0001 ; p<0,0001 ; p<0,0001 ; p<0,01$; $p<0,01 ; \quad p<0,01 ;$ and $p<0,01)$, father's education level with the incidence of stunting $(p<0,0001$ dan $p<0,01)$. There is a relationship between birth order of children, living with grandmother and polygamy with the incidence of stunting $(p<0,01 ; p<0,01, p<0,001)$. Socio demographic determinants of stunting events include: 1. residence (rural/urban), 2. Familyeconomic status, 3. Parental education, and 4. Contact with other culture, including the birth order, living with grandparents and polygamy.
\end{abstract}

Keywords: determinant; socio demographic; under five years; stunting; developing countries

\begin{abstract}
Abstrak
UNICEF melaporkan sebanyak 2/3 dari jumlah anak usia kurang dari 5 tahun di negara berpenghasilan menengah ke bawah mengalami stunting pada tahun 2014. Stunting merupakan prediktor buruknya kualitas sumber daya manusia dan menurunkan produktivitas suatu bangsa di masa yang akan datang. Literatur Review ini bertujuan untuk menganalisis determinan sosio-demografi kejadian stunting pada balita di berbagai negara berkembang. Desain penelitian ini adalah literature review dengan metode sistematik review. Artikel-artikel ditelusuri menggunakan beberapa search engine. Database google menjadi sumber utama dalam literature review ini. Kriteria inklusi dari artikel yang dipilih antara lain : 1) jurnal/laporan ilmiah, 2) Disajikan dalam bahasa inggris, 3) Terbit 10 tahun terakhir (tahun 2008 sampai tahun 2018), 4) Artikel menggunakan subjek penelitian adalah anak usia $<60$ bulan, dan 5) Artikel dengan desain correlation research. Ada hubungan positif tempat tinggal dengan kejadian stunting $(\mathrm{p}<0,0001 ; \mathrm{p}<0,05 ; \mathrm{p}<0,01 ; \mathrm{p}<0,0001)$. Ada hubungan negatif status ekonomi
\end{abstract}


keluarga dengan kejadian stunting $(\mathrm{p}<0,0001 ; \mathrm{p}<0,001 ; \mathrm{p}<0,001)$, tingkat pendidikan ibu dengan kejadian stunting $(\mathrm{p}<0,0001 ; \mathrm{p}<0,0001 ; \mathrm{p}<0,0001 ; \mathrm{p}<0,01 ; \mathrm{p}<0,01 ; \mathrm{p}<0,01 ;$ dan $\mathrm{p}<0,01)$, dan tingkat pendidikan ayah dengan kejadian stunting $(\mathrm{p}<0,0001$ dan $\mathrm{p}<0,01)$. Ada hubungan urutan kelahiran anak, tinggal bersama nenek, dan poligami dengan kejadian stunting $(\mathrm{p}<0,01 ; \mathrm{p}<0,01$, dan $\mathrm{p}<0,001)$. Determinan sosio demografi kejadian stunting meliputi: 1. Tempat tinggal (rural/urban), 2. Status ekonomi keluarga, 3. Tingkat pendidikan orang tua (ayah dan ibu), dan 4. Kontak dengan budaya lain, meliputi urutan kelahiran anak, tinggal bersama kakek/nenek, dan adanya poligami.

Kata kunci: determinan; sosio demografi; balita; stunting; negara berkembang

\section{PENDAHULUAN}

Stunting adalah gangguan pertumbuhan dan perkembangan otak pada anak yang disebabkan karena kekurangan asupan gizi dalam waktu lama, infeksi yang berulang, dan kurangnya stimulasi psikososial. ${ }^{1}$ Menurut World Health Organization (WHO) stunting didasarkan pada indeks Panjang Badan dibanding Umur $(\mathrm{PB} / \mathrm{U})$ atau Tinggi Badan dibanding Umur $(\mathrm{TB} / \mathrm{U})$ dengan batas (z-score) kurang dari -2 SD. ${ }^{2,3}$ Dampak dari stunting diantaranya adalah meningkatnya risiko morbiditas, mortalitas, keterlambatan perkembangan motorik danmental, serta menurunnya kapasitas kerja. Stunting yang merupakan penanda dari malnutrisi kronis/ rendahnya kesehatan ibu, dapat memberikan dampak jangka panjang dan bersifat irreversible jika terjadi setelah anak berumur 2 tahun. ${ }^{4}$

Sepertiga dari jumlah populasi anak di dunia mengalami stunting. ${ }^{5}$ Berdasarkan data UNICEF, WHO, dan World Bank (2015), diperkirakan sebanyak 159 juta anak usia kurang dari 5 tahun lebih pendek dibandingkan dengan standar anak seusianya (stunted). Data UNICEF juga menunjukkan bahwa pada tahun 2014, sebanyak 2/3 dari jumlah anak usia kurang dari 5 tahun di negara berpenghasilan menengah ke bawah mengalami stunting. ${ }^{6}$ Laporan penelitian lain menunjukkan bahwa setiap tahun sekitar 250 juta anak usia kurang dari 5 tahun di negaranegara berpenghasilan rendah dan menengah mengalami perkembangan yang kurang optimal dikarenakan kemiskinan dan stunting. ${ }^{3}$ Stunting masih merupakan permasalahan gizi yang utama di dunia.

Berdasarkan laporan WHO (Gambar 1), lebih dari setengahnya anak-anak stunting berusia di bawah 5 tahun hidup di Asia dan lebih dari sepertiganya tinggal di Afrika. Angka prevalensi stunting terbesar antara lain Oceania 38,1\%, Afrika Timur 35,6\%, Asia Selatan 33,3\%, dan Afrika Tengah 32,1\%. Data menunjukan $25 \%$ dari semua anak stunting tinggal di negara dengan pendapatan rendah, 66\% dari semua anak stunting tinggal di negara dengan pendapatan menengah, dan $8 \%$ dari semua anak stunting tinggal di negara dengan pendapatan tinggi. ${ }^{7}$

Stunting akan menjadi permasalahan tersendiri bagi sebuah negara. Dampak dari stunting bukan hanya kegagalan untuk mencapai potensi genetik seseorang, tetapi juga merupakan prediktor dari banyak kendala perkembangan lainnya, termasuk defisit kognitif dan kehilangan peluang ekonomi di masa depan. Suatu studi menemukan bahwa suatu negara yang memiliki anak stunting akan membutuhkan biaya untuk intervensi. Diketahui sekitar 2,2 milyar dolar-2,6 milyar dolar dari pemerintah negara dihabiskan secara global setiap tahun untuk melakukan intervensi pada anak-anak stunting. Biaya intervensi akan difokuskan pada ketersediaan dan keanekaragaman pangan, pendidikan perempuan, pemberdayaan dan kesehatan perempuan, dan air, sanitasi dan kebersihan. ${ }^{8}$

Studi menunjukan bahwa anak stunting sangat berhubungan dengan prestasi pendidikan yang buruk, lama pendidikan yang menurun dan pendapatan yang rendah sebagai orang dewasa. Anak-anak stunting menghadapi kemungkinan yang lebih besar untuk tumbuh menjadi orang dewasa yang kurang pendidikan, miskin, kurang sehat dan lebih rentan terhadap penyakit tidak menular. Berdasarkan hal tersebut, anak stunting merupakan prediktor buruknya kualitas sumber daya manusia dan menurunkan kemampuan produktif suatu bangsa di masa yang akan datang. ${ }^{7}$

Stunting dipengaruhi oleh berbagai determinan yang sangat kompleks, meskipun 
secara umum diketahui bahwa stunting terjadi karena kurangnya asupan zat gizi, penyakit infeksi kronis, dan penyakit parasit pada usus. ${ }^{(9)}$ Berbagai variabel sosio demografi juga berkaitan dengan kejadian stunting. Laporan ini menunjukkan berbagai determinan sosio demografi yang berkaitan dengan kejadian stunting pada balita di berbagai negara berkembang di dunia, termasuk Indonesia .

\section{BAHAN DAN METODE}

Desain penelitian ini adalah literature review. Literature review ini disusun dengan menggunakan metode sistematik review dengan mengumpulkan artikel-artikel menggunakan beberapa search engine guna menelusuri materi artikel terkait kejadian stunting pada anak. Database google menjadi sumber utama dalam literature review ini. Engine yang digunakan diantaranya adalah MEDLINE-EBSCO, Sciencedirect, ResearchGate, dan google search engine dengan kata kunci stunting, stunting determinant, under 5 years, stunting in children, dan child. Adapun kriteria inklusi dari artikel yang dipilih antara lain : 1) jurnal/laporan ilmiah, 2) Disajikan dalam bahasa inggris, 3) Terbit 10 tahun terakhir (tahun 2008 sampai tahun 2018), 4) Artikel menggunakan subjek penelitian anak usia $<60$ bulan, dan 5) Artikel dengan desain correlation research.

\section{HASIL}

\section{Tabel 1 menampilkan hasil analisis Determinan}

Sosio Demografi Kejadian Stunting pada Balita di Berbagai Negara Berkembang:

Berdasarkan hasil literature review yang dilakukan, faktor sosio demografi yang berhubungan dengan stunting antara lain tempat tinggal (urban atau rural), tingkat ekonomi keluarga, pendidikan ibu dan pendidikan ayah, dan kontak dengan budaya lain (urutan kelahiran anak, tinggal bersama nenek dan atau kakek, dan poligami).

\section{PEMBAHASAN}

Kejadian stunting pada anak merupakan suatu proses kumulatif. Proses ini terjadi sejak kehamilan, masa kanak-kanak, dan sepanjang siklus kehidupan. Proses terjadinya stunting pada anak dan peningkatan peluang terjadinya stunting ada dalam periode 2 tahun pertama kehidupan seorang anak. Banyak faktor yang dapat menyebabkan stunting pada anak, antara lain lingkungan, keturunan, perilaku, dan sosio demografi. Faktor determinan tersebut saling mempengaruhi satu sama lainnya. ${ }^{10}$

Menurut kerangka konseptual yang dirumuskan oleh UNICEF diketahui bahwa faktor yang berhubungan secara langsung dengan pertumbuhan adalah asupan makanan dan penyakit infeksi, sedangkan faktor yang berhubungan secara tidak langsung antara lain ketahanan pangan keluarga, pola asuh anak dalam keluarga, sanitasi lingkungan, dan pemanfaatan pelayanan kesehatan. ${ }^{27}$ Faktor sosio demografi mempunyai andil dalam kejadian stunting, walaupun pengaruhnya tidak secara langsung.

Determinan stunting di negara berkembang dijabarkan berdasarkan WHO, antara lain dibagi menjadi lingkungan, keturunan, perilaku, dan sosio demografi. Hal ini dapat dilihat pada Gambar 1. Sosio demografi dapat berupa sosial ekonomi, kemiskinan, dan keamanan pangan. Keturunan merupakan faktor biologi yang diturunkan dari orang tua. Lingkungan dapat berupa suplai makanan, kuantitas makanan, aspek sosial dan budaya, daerah urban, dan tren hukum makanan. Perilaku bisa berupa gaya hidup dan kebiasaan serta faktor psikologi. ${ }^{10}$

Stunting padamasaanak-anak mempunyai konsekuensi seumur hidup, tidak hanya berkaitan dengan permasalahan kesehatan, tetapi juga terkait dengan kemiskinan dan kesetaraan. ${ }^{11} \mathrm{Hal}$ yang paling penting, kekurangan gizi kronis bisa terjadi karena siklus antar generasi ke generasi atau herediter. Ibu yang kekurangan gizi cenderung mempunyai anak dengan gizi yang kurang. ${ }^{12}$ Beberapa penelitian dari berbagai negara menunjukan berbagai faktor determinan sosio demografi yang terbukti secara statistik berhubungan dengan stunting. Berikut adalah gambar analisis determinan sosio demografi yang berhubungan dengan stunting. ${ }^{(13)}$ 
In 7 sub-regions, at least one in every four children under 5 is stunted Percentage of stunted children under 5, by United Nations sub-region, 2017

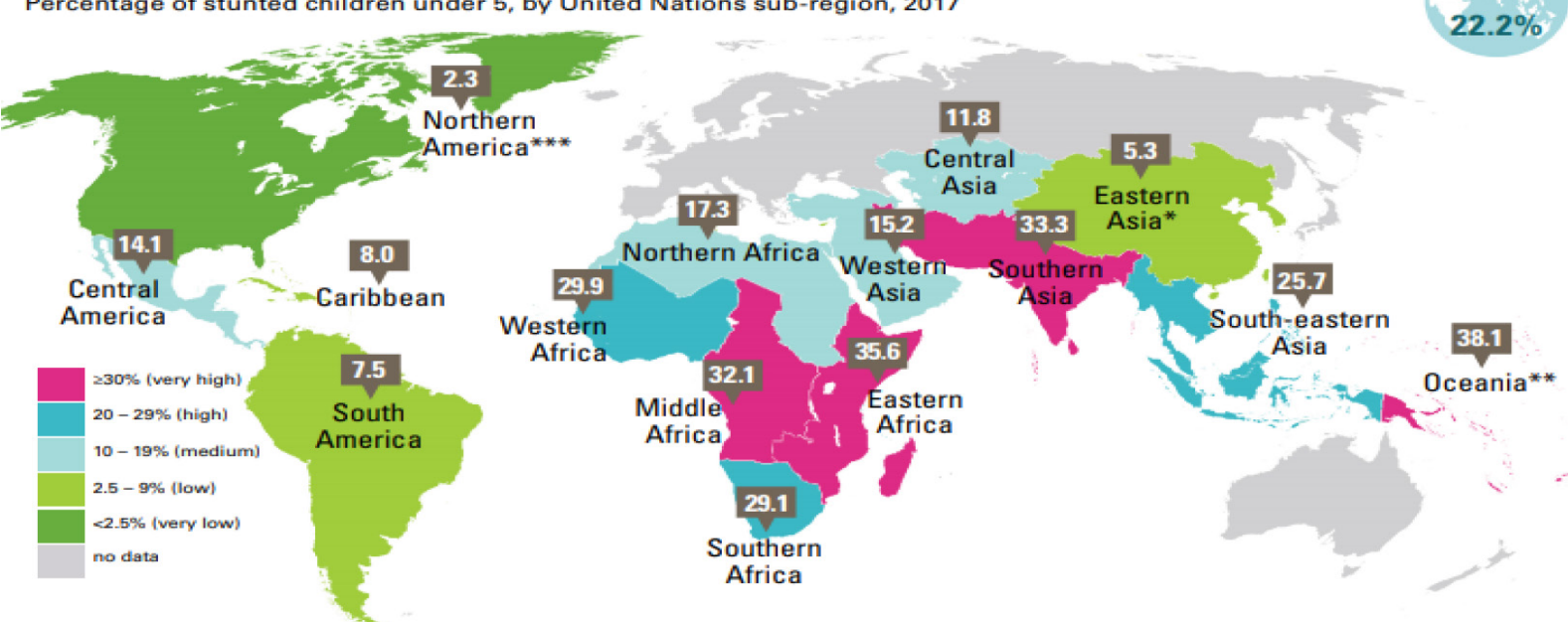

Source: UNICEF, WHO, World Bank Group joint malnutrition estimates, 2018 edition. Note: *Eastern Asia excluding Japan; - -Oceania excluding Australia and New Zealand. *-Northern Ammenca sub-regional average based on United States data. There is no estimate available for the sub-regions of Europe or Australla and New Zealand. These maps are

\section{Gambar 1. Peta Prevalensi Stunting di Dunia Tahun 2017}

\section{Gambar 2. Diagram Alir Proses Penelusuran Database}

101 artikel diperoleh dari penelusuran database.

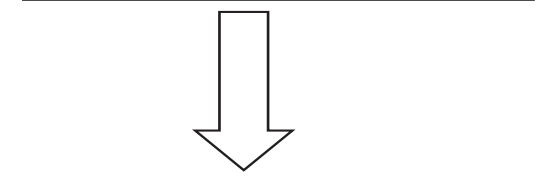

35 artikel direview

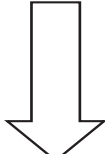

14 artikel direview lebih lanjut
66 artikel dieksklusi

berdasarkan judul dan

abstrak

21 artikel dieksklusi setelah direview (fulltext)

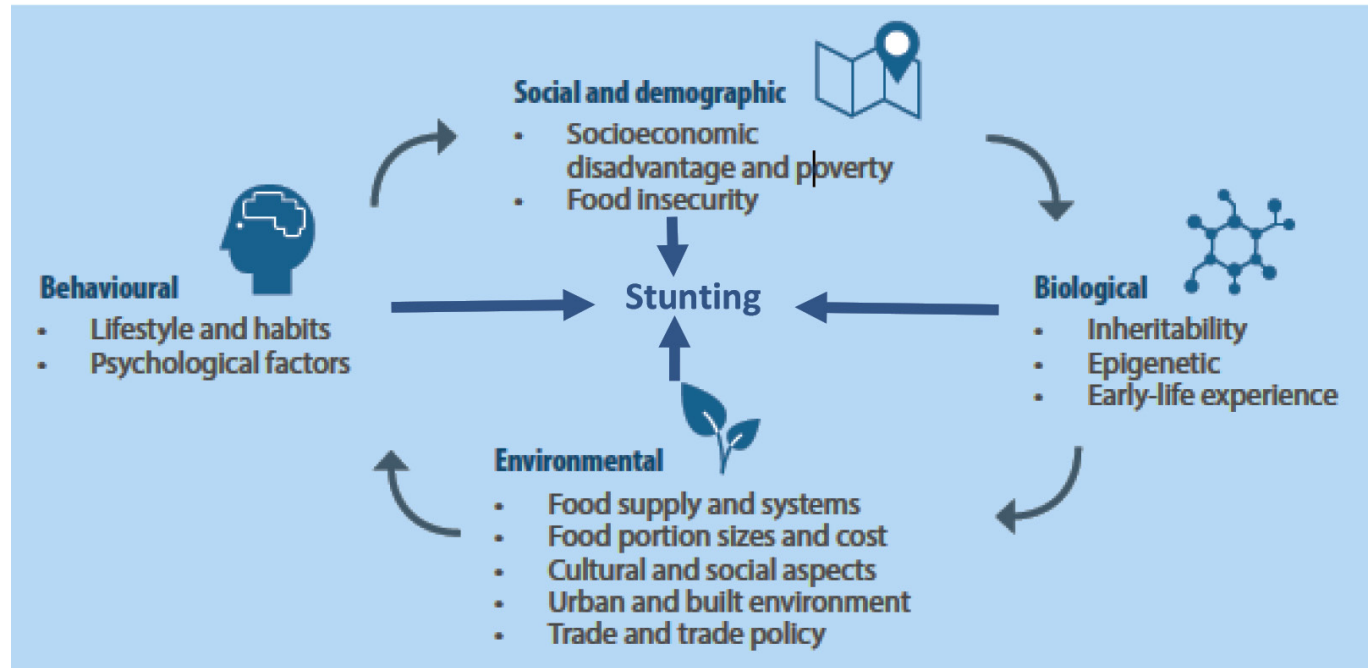

Gambar 2. Faktor Determinan Stunting 


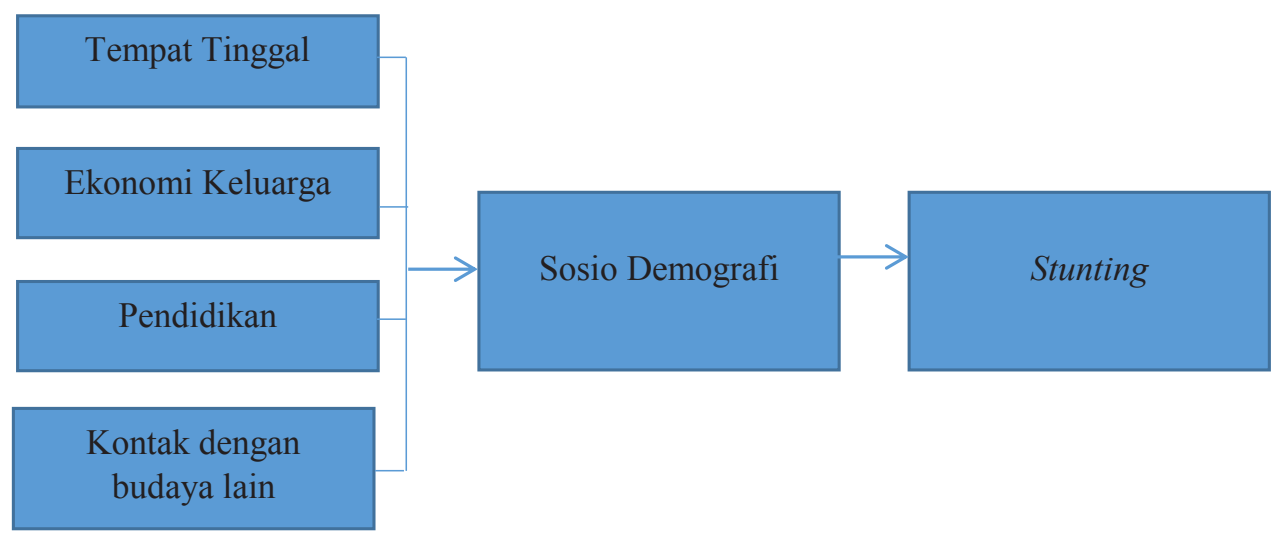

Gambar 3. Determinan Sosio Demografi Stunting

Tabel 1. Hasil Analisis Determinan Sosio Demografi Kejadian Stunting pada Balita di Berbagai Negara Berkembang

\begin{tabular}{|c|c|c|c|c|c|}
\hline \multirow{2}{*}{ No } & \multirow{2}{*}{ Variabel Sosio Demografi } & \multicolumn{3}{|c|}{ Kejadian Stunting } & \multirow{2}{*}{ Negara } \\
\hline & & $\mathbf{P}$ & PR/OR & CI 95\% & \\
\hline \multirow[t]{7}{*}{1} & Tempat tinggal (rural/urban) & $\mathrm{p}<0,0001$ & 1,136 & $1,075-1,202$ & Bangladesh $^{14}$ \\
\hline & & $\mathrm{P}<0,05$ & 1,37 & $1,01-1,86$ & Guatemala $^{15}$ \\
\hline & & $\mathrm{P}<0,01$ & 1,12 & Tidak disebutkan & Afrika $^{16}$ \\
\hline & & $<0,0001$ & Tidak disebutkan & Tidak disebutkan & Afghanistan $^{17}$ \\
\hline & & $\mathrm{P}<0,001$ & Tidak disebutkan & Tidak disebutkan & dataran tinggi ekuador ${ }^{18}$ \\
\hline & & 0,019 & 1,40 (rural) & $1,06-1,85$ & Tanzania $^{19}$ \\
\hline & & 0,004 & Tidak disebutkan & Tidak disebutkan & India $^{12}$ \\
\hline \multirow[t]{10}{*}{2} & Ekonomi keluarga & & & & \\
\hline & Pengeluaran per kapita $>\$ 10$ & $\mathrm{P}<0,0001$ & 0,819 & $0,792-0,847$ & Bangladesh $^{14}$ \\
\hline & Ketidakseimbangan ekonomi & $\mathrm{P}<0,001$ & Tidak disebutkan & $0,19-0,25$ & Guatemala $^{15}$ \\
\hline & Kesejahteraan rumah tangga (IWI) & $\mathrm{P}<0,001$ & 0,99 & Tidak disebutkan & Afrika $^{16}$ \\
\hline & Status ekonomi & 0,030 & 0,79 & $0,64-0,98$ & dataran tinggi ekuador ${ }^{18}$ \\
\hline & Kemiskinan & $\mathrm{p}<0,001$ & 2 & $1,6-2,3$ & Burundi, Afrika ${ }^{20}$ \\
\hline & & $\mathrm{p}<0,001$ & Tidak disebutkan & Tidak disebutkan & (Israel) Brazil ${ }^{21}$ \\
\hline & & $\mathrm{p}<0,001$ & Tidak disebutkan & Tidak disebutkan & Indonesia $^{22}$ \\
\hline & & 0,002 & 1,85 (sangat miskin) & $1,25-2,74)$ & Tanzania $^{19}$ \\
\hline & & 0,001 & 1,7 & $1,19-2,22$ & Egypt $^{23}$ \\
\hline \multirow[t]{13}{*}{3} & Pendidikan ibu & $\mathrm{p}<0,0001$ & 0,956 & $0,950-0,961$ & Bangladesh (urban) ${ }^{14}$ \\
\hline & & $\mathrm{p}<0,0001$ & 0,950 & $0,946-0,954$ & Bangladesh (rural) $)^{14}$ \\
\hline & & $\mathrm{p}<0,0001$ & 0,954 & $0,951-0,957$ & Bangladesh (rural dan urban) $)^{14}$ \\
\hline & & $\mathrm{p}<0,01$ & 2,5 & $1,54-4,03$ & pada anak perempuan India ${ }^{24}$ \\
\hline & & $\mathrm{p}<0,01$ & 0,2 & $0,1-0,42$ & Ethiopia (pendidikan primer) ${ }^{25}$ \\
\hline & & $\mathrm{p}<0,01$ & 0,1 & $0,02-0,44$ & $\begin{array}{l}\text { Ethiopia (pendidikan } \\
\text { sekunder) }^{25}\end{array}$ \\
\hline & & $\mathrm{P}<0,01$ & 0,01 & $0,001-0,063$ & Ethiopia $^{25}$ \\
\hline & & $\mathrm{p}<0,001$ & 2,3 & $1,7-3$ & Burundi, Afrika ${ }^{20}$ \\
\hline & & 0,025 & 0.95 & $0.92-0,99$ & Dataran tinggi ekuador ${ }^{18}$ \\
\hline & & $<0,001$ & Tidak disebutkan & Tidak disebutkan & Egypt $^{23}$ \\
\hline & & $\begin{array}{l}<0,001 \text { (no } \\
\text { education) }\end{array}$ & 2,26 & $1,41-3,6$ & Tanzania $^{19}$ \\
\hline & & 0,000 & Tidak disebutkan & Tidak disebutkan & India $^{12}$ \\
\hline & & 0,001 & 3,0 & $2,14-4,26$ & Egypt $^{23}$ \\
\hline
\end{tabular}




\begin{tabular}{|c|c|c|c|c|c|}
\hline \multirow[t]{2}{*}{4} & Pendidikan ayah & $\mathrm{p}<0,0001$ & 0,970 & $0,967-0,974$ & Bangladesh $^{14}$ \\
\hline & & $\mathrm{p}<0,01$ & 3,3 & $1,96-5,58$ & India (pada anak perempuan) ${ }^{24}$ \\
\hline \multirow[t]{2}{*}{5} & Urutan kelahiran anak & $\mathrm{p}<0,01$ & 2,49 & $1,54-4,03$ & India $^{24}$ \\
\hline & & $\mathrm{p}<0,05$ & 3,1 & $0,98-9,92$ & Ethiopia (anak ke $4-5)^{25}$ \\
\hline 6 & Tinggal bersama nenek & $\mathrm{p}<0,01$ & 0,95 & Tidak disebutkan & Afrika $^{16}$ \\
\hline \multirow[t]{2}{*}{7} & Tinggal bersama kakek & $\mathrm{p}>0,05$ & - & - & Afrika $^{16}$ \\
\hline & $\begin{array}{l}\text { Tinggal bersama kakek*jenis } \\
\text { kelamin anak }\end{array}$ & $\mathrm{p}<0,001$ & 0,90 & Tidak disebutkan & Afrika $^{16}$ \\
\hline 8 & Poligami*Tinggal bersama kakek & $\mathrm{P}<0,001$ & 0,86 & Tidak disebutkan & Afrika $^{16}$ \\
\hline
\end{tabular}

Berdasarkan hasil literature review yang dilakukan, faktor sosio demografi yang berhubungan dengan stunting antara lain tempat tinggal (urban atau rural), tingkat ekonomi keluarga, pendidikan ibu dan pendidikan ayah, dan kontak dengan budaya lain (urutan kelahiran anak, tinggal bersama nenek dan atau kakek, dan poligami).

\section{Tempat tinggal}

Data pertama dari penelitian yang dilakukan di 2 negara yaitu Indonesia dan Bangladesh, yaitu bahwa tempat tinggal (rural vs urban) berdasarkan hasil uji regresi logistik berpengaruh terhadap kejadian stunting $(p<0,0001)$ dengan $\operatorname{PR}(95 \% \mathrm{CI})=1,136(1,075$ $-1,202)$. Hal ini berarti, balita yang tinggal di wilayah rural memiliki risiko 1,136 kali lebih besar untuk mengalami stunting, dibandingkan balita yang tinggal di wilayah urban. ${ }^{14}$ Data kedua dari Guatemala menunjukkan bahwa tempat tinggal (rural/urban) berdasarkan hasil uji regresi logistik berpengaruh terhadap kejadian stunting $(\mathrm{p}<0,05)$ dengan $\mathrm{PR}(95 \% \mathrm{CI})=1,37$ $(1,01-1,86)$. Hal ini berarti, balita yang tinggal di wilayah rural memiliki risiko 1,37 kali lebih besar untuk mengalami stunting, dibandingkan balita yang tinggal di wilayah urban. ${ }^{15}$

Data ketiga dari Subsaharan-Afrika menunjukkan bahwa tempat tinggal (rural/ urban) berdasarkan hasil uji regresi logistik berpengaruh terhadap kejadian stunting $(p<0,01)$ dengan $\mathrm{PR}=1,12$. Hal ini berarti, balita yang tinggal di wilayah rural memiliki risiko 1,12 kali lebih besar untuk mengalami stunting, dibandingkan balita yang tinggal di wilayah urban. ${ }^{26}$ Data keempat, penelitian yang dilakukan di Afghanistan menunjukkan bahwa tempat tinggal (rural/urban) berhubungan dengan kejadian stunting pada balita dengan $\mathrm{p}<0,0001$. Balita yang tinggal di wilayah rural lebih berisiko mengalami stunting dibandingkan balita yang tinggal di wilayah urban. ${ }^{17}$ Penelitian lain yang dilakukan di Tanzania, menyatakan bahwa anak umur 0-23 bulan yang tinggal di daerah pedesaaan (rural) berisiko stunting 1,4 kali lebih besar dibandingkan dengan anak yang tinggal di daerah kota. ${ }^{19}$

Determinan tempat tinggal terbagi ke dalam dua kelompok, yaitu desa dan kota. anak yang tinggal di desa (rural) mempunyai risiko lebih besar terkena stunting dibandingkan dengan anak yang tinggal di daerah kota (urban). ${ }^{14,15,17,26}$ Di daerah pedesaan, risiko stunting yang lebih besar dikaitkan dengan karakteristik keluarga, penghasilan keluarga, alokasi sumber daya rumah tangga, organisasi keluarga, jejaring sosial, dan perawatan kesehatan anak. ${ }^{28}$

Lingkungan desa dan kota berbeda, lingkungan tempat tinggal akan menentukan jenis pekerjaan ayah dan besar pendapatan yang diperoleh. ${ }^{28}$ Perbedaan lingkungan desa dan kota juga terkait dengan ketersediaan makanan yang bergizi. Di desa, ketersediaan makanan tergantung pada produksi lokal yang ada, sedangkan di kota cenderung tersedia makanan yang beraneka ragam. Di Kota, makanan yang beraneka ragam juga mudah didapatkan. Pemenuhan kebutuhan tersebut tergantung pada kemampuan keluarga untuk memenuhi kebutuhan 
hidupnya. Selain hal tersebut, jejaring sosial juga mempunyai dampak yang signifikan terhadap stunting di desa dan di kota. Di kota, orang tua lebih mudah mengakses internet untuk mencari informasi terkait kesehatan anak, sehingga orang tua mempunyai pengetahuan yang cukup untuk mengatasi permasalahan kesehatan pada anak. Fasilitas kesehatan yang tersedia di desa dan di kota juga berbeda.

Penelitian lain menyebutkan perbedaan kota dan desa antara lain terletak pada akses fasilitas kesehatan, faktor ibu (Tinggi Badan (TB) dan Indeks Massa Tubuh (IMT) ibu), pemberian asi eksklusif, dan pendidikan ibu. Di kota, orang tua cenderung lebih mudah mengakses pelayanan kesehatan dibandingkan orang tua di desa. Berkaitan dengan TB dan IMT ibu, dilaporkan bahwa di daerah urban semakin tinggi IMT ibu maka semakin rendah risiko stunting pada anak, sedangkan di daerah rural dilaporkan bahwa TB ibu berhubungan positif dengan TB anak. Namun, faktor ibu bukanlah faktor utama berkaitan dengan kejadian stunting pada anak. Status morbiditas anak dan asupan makan pada anak lebih erat kaitannya dengan kejadian stunting. ${ }^{18}$

\section{Ekonomi keluarga}

Tingkat ekonomi merupakan salah satu dari determinan stunting. Beberapa penelitian menyebutkan bahwa anak dari tingkat ekonomi rendah cenderung berisiko stunting. ${ }^{14,15,26}$ Tingkat ekonomi tidak lepas dari tingkat pendapatan seseorang. Tingkat pendapatan merupakan faktor penentu dalam kualitas dan kuantitas makanan yang disediakan dalam sebuah keluarga. Pendapatan yang rendah akan mengakibatkan lemahnya dayabeli sehingga tidak memungkinkan untuk mengatasi kebiasaan makan secara efektif terutama untuk anak, sedangkan pendapatan yang meningkat berpengaruh terhadap perbaikan kesehatan dan keadaan gizi.

Data pertama dari penelitian yang dilakukan di Indonesia dan Bangladesh menunjukkan bahwa pengeluaran per kapita per minggu (per $\$ 10$ ) berpengaruh terhadap kejadian stunting $(\mathrm{p}<0,0001)$ dengan $\mathrm{PR}(95 \%$ CI $)=0,819(0,792-0,847)$. Artinya, balita yang pengeluaran per kapita per minggu dalam keluarganya per \$10 maka akan terproteksi dari kejadian stunting $(0,819)$ dibandingkan balita yang tinggal dalam keluarga dengan pengeluaran per kapita per minggu dalam keluarganya $<\$ 10$. ${ }^{14}$ Data kedua dari penelitian yang dilakukan di Guatemala bahwa ketidakseimbangan ekonomi berhubungan signifikan dengan kejadian stunting. Nilai $\mathrm{p}<0,001 ; 95 \% \mathrm{CI}=0,25-0,19$. (15) Data ketiga dari penelitian yang dilakukan di Subsaharan-Afrika menunjukkan bahwa kesejahteraan rumah tangga (IWI) berpengaruh terhadap kejadian stunting pada balita berdasarkan analisis regresi logistik $(\mathrm{p}<0,001)$. Semakin tinggi kesejahteraan keluarga maka risiko kejadian stunting akan semakin turun, akan tetapi temuan yang menarik adalah jika dalam keluarga tersebut ada kakek yang tinggal bersama, maka hubungan kesejahteraan keluarga dengan kejadian stunting akan melemah. Hal ini berarti bahwa seorang kakek yang tinggal bersama dapat memegang kendali dalam sumber daya (termasuk sumber daya ekonomi) yang ada dalam rumah tangga miskin, tetapi juga dimungkinkan bahwa kakek cenderung untuk bersaing terkait sumber daya dengan cucu mereka di rumah tangga yang kaya. ${ }^{26}$ Jadi, keberadaan seorang kakek yang tinggal bersama dalam suatu keluarga akan mendukung kesejahteraan ekonomi bagi keluarga miskin, tetapi dapat juga melemahkan kesejahteraan keluarga kaya karena cenderung akan bersaing dengan cucu mereka dalam alokasi sumber daya dalam keluarga tersebut.

Status ekonomi terbukti sebagai salah satu faktor stunting pada anak dibawah lima tahun. ${ }^{18,20-22}$ Negara berkembang merupakan negara yang mempunyai penduduk miskin. Kemiskinan tersebut merupakan faktor pencetus ketidakseimbangan ekonomi keluarga. Balita yang berasal dari keluarga miskin mempunyai potensi besar untuk menderita stunting. Keluarga miskin memiliki kesejahteraan yang tidak seimbang, sehingga dapat mengalami kesulitan dalam pemenuhan gizi keluarga.

Negara berkembang seperti di India, Indonesia, Bangladesh, dan Guatemala merupakan negara dengan tingkat ekonomi menengah. Negara berkembang seperti 
Afganistan dan Ethiopia mempunyai tingkat ekonomi yang rendah. Hal ini menjadikan negaranegara tersebut mempunyai faktor risiko stunting yang lebih besar dibandingkan dengan negara maju. Negara dengan tingkat ekonomi menengah dan lemah, mempunyai arti pengahasilan rata-rata per kapitanya juga menengah dan lemah. Data UNICEF tahun 2018 menunjukan bahwa negaranegara dengan tingkat ekonomi menengah ke bawah mempunyai angka prevalensi stunting $>$ $35 \%$ dari total sampel survei. ${ }^{29}$

\section{Pendidikan}

Pendidikan merupakan salah satu determinan penting dari kejadian stunting pada balita. Data pertama menunjukkan bahwa tingkat pendidikan ayah dan ibu secara signifikan berhubungan dengan penurunan risiko kejadian stunting. Pendidikan ibu dan pendidikan ayah berhubungan dengan penurunan risiko kejadian stunting dengan nilai $\mathrm{p}<0,0001$ dan OR $(95 \% \mathrm{CI})$ : $0,954(0,951-0,957)$ dan $0,970(0,967-0,974) .{ }^{14}$

Data kedua, penelitian di India menunjukkan bahwa status pendidikan status pendidikan ayah $(\mathrm{p}<0,001)$, dan status pendidikan ibu ( $p>0,001)$ berhubungan signifikan dengan prevalensi stunting pada anak perempuan. Status pendidikan ayah $($ Wald $=19,97, \mathrm{p}<0,001)$ dan status pendidikan ibu (Wald $=13,95, \mathrm{p}<0,001$ ) merupakan prediktor yang kuat dari kejadian stunting pada anak perempuan. Anak perempuan dengan status pendidikan ayah kurang dari SMP memiliki risiko lebih tinggi mengalami stunting daripada ayah dengan status pendidikan lebih tinggi $(\mathrm{OR}=3,30, \mathrm{CI}=1.96-5.58)$. Anak perempuan dengan status pendidikan ibu kurang dari SMP memiliki risiko lebih tinggi mengalami stunting daripada anak perempuan dengan status pendidikan ibu lebih tinggi $(\mathrm{OR}=2.50, \mathrm{CI}=$ $1.54-4.03){ }^{24}$

Data ketiga penelitian di Guatemala menunjukkan bahwa pendidikan ibu berhubungan dengan prevalensi stunting pada anak. Prevalensi anak stunting pada ibu dengan pendidikan rendah (no education) sebesar 63,8\%, lebih tinggi daripada prevalensi anak stunting pada ibu dengan pendidikan menengah (elementary) yaitu sebesar 44,5\% dan pendidikan tinggi (secondary/ higher) yaitu sebesar $18,9 \% .^{15}$

Data keempat penelitian di Subsaharan Afrika menunjukkan bahwa pendidikan ayah dan pendidikan ibu berhubungan signifikan dengan kejadian stunting $(\mathrm{p}<0,001 ; \mathrm{OR}=0,99$ dan $\mathrm{p}<$ 0,$001 ; \mathrm{OR}=0,97$ ). Selain itu, pendidikan kakek juga berhubungan dengan kejadian stunting pada anak. Pendidikan kakek berhubungan negatif dengan kejadian stunting pada anak $(\mathrm{OR}=0,99)$, sedangkan pendidikan nenek tidak berhubungan dengan kejadian stunting $(\mathrm{OR}=1) \cdot{ }^{26}$ Data kelima penelitian di Ethiopia Utara yang menunjukkan hasil bahwa status pendidikan ibu berhubungan negatif dengan kejadian stunting pada anak (AOR: 0.01, 95\% CI: 0.001-0.063). ${ }^{25}$

Penelitian lain juga menyebutkan ada hubungan antara pendidikan ibu terhadap stunting. Penelitian lain menyebutkan bahwa ibu yang mempunyai pendidikan rendah mempunyai risiko 2,3 kali lebih besar memiliki anak stunting dibandingkan dengan ibu yang mempunyai pendidikan tinggi $(\mathrm{p}<0,001$ dan CI : 1,7 -3). Anak-anak yang berasal dari keluarga yang kurang berpendidikan lebih banyak kemungkinan terhambat pertumbuhannya $(\mathrm{p}<0,001 ; \mathrm{cOR}=2,1$; CI : $1,4-3){ }^{20}$

Tingkat pendidikan ayah dan ibu berhubungan negatif dengan kejadian stunting pada anak balita. ${ }^{14,15,24-26}$ Namun, terdapat perbedaan pengaruh antara tingkat pendidikan ibu dan ayah dengan kejadian stunting pada balita laki-laki maupun perempuan. Pengaruh pendidikan ibu terhadap kejadian stunting sama besarnya di Indonesia maupun Bangladesh, tetapi pengaruh pendidikan ayah lebih kuat mempengaruhi stunting pada anak di Bangladesh. ${ }^{14}$

Peningkatan level pendidikan ibu dan ayah berhubungan signifikan dengan peningkatan kualitas pengasuhan. Akan tetapi, terdapat perbedaan pengaruh antara pendidikan ayah dan pendidikan ibu di Indonesia dan Bangladesh. Hal ini dikarenakan tingkat pendidikan ibu di Bangladesh rata-rata masih rendah. Perempuan Bangladesh menikah di usia yang lebih muda dibandingkan di Indonesia. Oleh karena itu, tingkat pendidikan ayah yang lebih berpengaruh terhadap pertumbuhan linear anak. Hal yang 
berbeda terjadi di Indonesia, di Indonesia perempuan biasanya menjadi pengasuh utama bagi anak-anaknya, sehingga tingkat pendidikan ibu turut menentukan kualitas pengasuhan dan mencegah terjadinya stunting pada anak. ${ }^{14}$ Studi lain juga menyebutkan bahwa pendidikan ibu merupakan faktor yang terkait dengan pertumbuhan anak. ${ }^{21}$ Cara ibu dalam menerapkan pola asuh akan berbeda jika tingkat pendidikan ibu berbeda. Cara ibu memperhatikan anak juga akan berbeda. Selain itu, akses ke pelayanan kesehatan juga dipengaruhi oleh tingkat pendidikan ibu.

Hal yang berbeda terjadi di India, pendidikan ayah dan pendidikan ibu keduanya berhubungan signifikan dengan kejadian stunting pada anak balita perempuan, tetapi tidak pada anak laki-laki. Hal tersebut dapat dikarenakan pada keluarga dengan pendidikan orang tua yang rendah cenderung mengaitkan urutan kelahiran dengan pengasuhan. Anak perempuan yang lahir setelah anak perempuan maka akan kurang mendapatkan perhatian dan kasih sayang dari kedua orang tuanya. ${ }^{24}$ Pada keluarga dengan tingkat pendidikan yang kurang cenderung lebih memperhatikan anak laki-laki dibandingkan anak perempuan.

Terdapat bukti yang kuat bahwa meningkatnya tingkat pendidikan orang tua (ayah dan ibu) serta pekerjaan ayah merupakan determinan dari pertumbuhan linear anak yang lebih baik, hal ini dikarenakan orang tua cenderung memiliki sumberdaya dan sumber informasi yang lebih baik dibandingkan orang tua dengan pendidikan rendah. Sumberdaya dan sumber informasi yang baik dibutuhkan untuk pertumbuhan anak yang sehat. ${ }^{30}$ Akan tetapi, dominasi pengaruh pendidikan ayah, pendidikan ibu, maupun keduanya terhadap kejadian stunting pada anak laki-laki maupun perempuan berbedabeda karena berkaitan dengan budaya setempat.

\section{Kontak dengan budaya lain}

Kontak dengan budaya lain yang dikaji dalam studi literatur ini meliputi urutan kelahiran anak, budaya tinggal bersama dengan kakek/ nenek, dan status poligami. Berdasarkan hasil kajian, diketahui bahwa ketiga variabel tersebut mempunyai hubungan yang signifikan dengan kejadian stunting pada balita.

\section{a. Urutan kelahiran anak}

Data pertama diperoleh dari penelitian yang dilakukan di Bengalee, India Timur, yaitu bahwa urutan kelahiran anak $(\mathrm{p}<0.001)$ berhubungan signifikan dengan prevalensi stunting pada anak perempuan. Anak perempuan dengan urutan kelahiran lebih dari sama dengan 3 mempunyai risiko lebih tinggi mengalami stunting dibandingkan anak dengan urutan kelahiran pertama dan kedua $(\mathrm{OR}=2.49, \mathrm{CI}=$ $1.54-4.03){ }^{24}$

Data kedua diperoleh dari hasil penelitian di Ethiopia Utara menunjukkan hasil berbeda. Berdasarkan penelitian tersebut, diketahui bahwa urutan kelahiran tidak berhubungan signifikan dengan kejadian stunting $(\mathrm{p} \geq 0,05) .{ }^{25}$

Urutan kelahiran berhubungan dengan kejadian stunting pada anak perempuan. Urutan kelahiran dan pendidikan orang tua merupakan prediktor kuat terjadinya stunting pada anak perempuan. Anak perempuan dengan urutan kelahiran lebih dari sama dengan 3 mempunyai risiko lebih tinggi 2,49 kali lebih besar untuk mengalami stunting dibandingkan anak dengan urutan kelahiran pertama dan kedua. Akan tetapi, urutan kelahiran tidak berhubungan dengan kejadian stunting pada anak laki-laki. ${ }^{24}$ Studi sebelumnya juga melaporkan bahwa urutan kelahiran secara signifikan berhubungan dengan kejadian stunting pada anak perempuan, tetapi tidak pada anak laki-laki. ${ }^{31}$ Hasil berbeda diperoleh dari hasil kajian di Ethiopia Utara. Urutan kelahiran tidak berhubungan signifikan dengan kejadian stunting. Akan tetapi, jenis kelamin anak berhubungan signifikan dengan stunting. Anak perempuan lebih tinggi risikonya untuk mengalami stunting dibandingkan anak laki-laki yang dimungkinkan terjadi karena pola asuh ibu yang bervariasi pada anak laki-laki dan perempuan. ${ }^{25}$

Bukti ini menunjukkan bahwa pada negara-negara berkembang, anak perempuan masih banyak mengalami diskriminasi gender. Keterbatasan sumberdaya yang dimiliki oleh suatu keluarga di negara-negara berkembang menyebabkan adanya diskriminasi pada anak perempuan. Harapan memiliki anak laki- 
laki yang dapat membantu meningkatkan perekonomian keluarga menyebabkan perhatian pada anak laki-laki lebih besar dibandingkan kepada anak perempuan. Terutama pada keluarga dengan tingkat pendidikan maupun ekonomi yang kurang cenderung lebih memperhatikan anak laki-laki dibandingkan anak perempuan.

\section{b. Tinggal bersama kakek/nenek}

Data diperoleh dari penelitian yang dilakukan di Subsaharan Afrika menunjukkan bahwa risiko kejadian stunting lebih rendah pada anak yang tinggal bersama neneknya (usia nenek antara 50-75 tahun) $(\mathrm{p}<0,01)$. Tidak ada hubungan tinggal bersama kakek dengan kejadian stunting secara umum, tetapi pada anak perempuan ada kaitan tinggal bersama kakek dengan menurunnya kejadian stunting pada anak perempuan di rumah tangga miskin dan ada poligami. ${ }^{26}$

Anak yang tinggal bersama neneknya dan dalam pengasuhan oleh nenek memiliki risiko lebih rendah untuk mengalami kejadian stunting dibandingkan dengan anak yang tidak tinggal bersama neneknya dan nenek berusia antara 50 - 75 tahun. Prevalensi anak stunting lebih tinggi ketika nenek yang tinggal bersama dengan keluarga berusia kurang atau lebih dari rentang tersebut. ${ }^{26}$ Usia nenek yang paling optimal sebagai faktor protektif adalah 65 tahun. ${ }^{16}$ Pada nenek yang berusia kurang atau lebih dari rentang tersebut, maka prevalensi anak stunting lebih tinggi. Hal tersebut dapat dikarenakan pada usia nenek yang kurang dari 50 tahun maka nenek masih dalam usia reproduktif sehingga tidak terlalu berperan dalam pengasuhan cucunya karena masih berperan sebagai orang tua yang mengasuh anak-anaknya sendiri. Pada usia lebih dari 70 tahun kemampuan fisik dan kesehatan nenek akan berkurang sehingga pengasuhan oleh nenek juga sudah kurang optimal. ${ }^{26,32}$ Tinggal bersama kakek tidak berhubungan dengan kejadian stunting secara umum, tetapi pada anak perempuan ada kaitan tinggal bersama kakek dengan menurunnya kejadian stunting. Cucu perempuan memiliki kelekatan yang lebih tinggi pada kakeknya dibandingkan cucu laki-laki. Keberadaan kakek juga dapat menggantikan peran orangtua yang hilang/kurang bagi cucu perempuan. ${ }^{26}$

\section{c. Poligami}

Data keterkaitan antara poligami dengan kejadian stunting diperoleh dari penelitian yang dilakukan di Subasaharan Afrika $(p<0,001)$. Rumah tangga yang orang tuanya melakukan poligami berhubungan dengan peluang kejadian stunting yang lebih tinggi. Akan tetapi, ketika kakeknya tinggal bersama maka peluang kejadian stunting akan menurun secara substansial $(\mathrm{p}<0,01)$. Peluang kejadian stunting pada keluarga dengan poligami berkurang sebesar 14\% ketika ada kakek yang tinggal dalam keluarga tersebut. ${ }^{26}$

Peluang kejadian stunting lebih tinggi pada rumah tangga yang ayahnya melakukan poligami $(\mathrm{OR}=1,09)$. Akan tetapi, ketika kakeknya tinggal bersama dalam keluarga, maka peluang kejadian stunting akan menurun secara substansial. Peluang kejadian stunting pada balita perempuan dengan orangtua poligami berkurang sebesar 14\% ketika ada kakek yang tinggal dalam keluarga tersebut. ${ }^{26}$ Hal ini berkaitan dengan kontribusi kakek yang dapat menggantikan peran orang tua yang kurang/hilang. Kakek juga lebih dominan dalam penguasaan sumber daya yang dimiliki oleh keluarga tersebut. Status poligami bukan merupakan prediktor yang kuat untuk terjadinya stunting pada balita. Berbagai prediktor lain yang memiliki hubungan yang lebih erat dengan kejadian stunting yaitu tempat tinggal, ekonomi keluarga, dan pendidikan orang tua. ${ }^{14,15,17,24-26}$

\section{KESIMPULAN}

Berdasarkan hasil dan pembahasan dalam review literatur ini dapat disimpulkan bahwa determinan sosio demografi kejadian stunting pada balita di berbagai negara Berkembang meliputi: 1. Tempat tinggal (rural/urban), 2. Status ekonomi keluarga, 3. Tingkat pendidikan orang tua (ayah dan ibu), dan 4. Kontak dengan budaya lain, meliputi urutan kelahiran anak, adanya kakek/nenek yang tinggal bersama, dan adanya poligami. 
Determinan yang paling berisiko terhadap kejadian stunting adalah status ekonomi keluarga dan status pendidikan ibu. Status ekonomi berkaitan dengan pendidikan orang tua, pekerjaan orang tua (khususnya ayah), dan pendapatan keluarga. Status ekonomi juga berkaitan dengan tempat tinggal rural/urban. Status ekonomi dan tingkat pendidikan berhubungan negatif dengan kejadian stunting. Semakin tinggi status ekonomi maupun tingkat pendidikan orang tua, maka peluang terjadinya stunting pada anak semakin menurun. Keluarga yang bertempat tinggal di desa (urban) lebih berisiko mempunyai anak stunting dibandingkan yang tinggal di kota (urban). Selain itu, pada beberapa negara berkembang masih ditemukan adanya kontak budaya yang berkaitan dengan kejadian stunting seperti urutan kelahiran anak, adanya kakek/nenek yang tinggal bersama, maupun status ayah yang poligami (mempunyai istri lebih dari 1 orang).

Diketahui bahwa status ekonomi dan tingkat pendidikan ibu merupakan determinan utama terhadap kejadian stunting. Oleh karenanya, kedua variabel tersebut perlu diprioritaskan dalam rencana strategi nasional untuk mengatasi stunting. Di level masyarakat, diperlukan adanya pemberian informasi dan peningkatan kapasitas ibu maupun ayah dari balita mengenai stunting, dampak, dan pencegahannya, termasuk variabel-variabel sosio demografi yang penting dan masih dapat diubah untuk mengoptimalkan pertumbuhan dan perkembangan anak.

\section{DAFTAR RUJUKAN}

1. Tim Nasional Percepatan Penanggulangan Kemiskinan. 100 Kabupaten/Kota Prioritas untuk Intervensi Anak Kerdil (stunting). 1st ed. Jakarta; 2017. 5-7 p.

2. World Health Organization Working Group on Infant Growth. An evaluation of infant growth : the use and interpretation of anthropometry in infants. WHO Bulletin. 1995;165-74.

3. Lo S, Das P, Horton R. Early childhood development: the foundation of sustainable. Lancet. 2017;389(2011):9-11.

4. Lewit EM, Kerrebrock N. Population-based growth stunting. The Future of Children. Child Poverty. 2019;7(2):149-56.
5. Onis M De, Blössner M, Borghi E, Morris R, Frongillo EA. Methodology for estimating regional and global trends of child malnutrition. Int J Epidemiol. 2005;33(6):1260-70.

6. Unicef, WHO, Bank TW. An evaluation of infant growth: the use and interpretation of anthropometry in infants. 2015.

7. UNICEF, WHO, World Bank. LEVELS AND TRENDS IN CHILD MALNUTRITION [Internet]. 2018 [cited 2019 Jan 23]. Available from: https://www.who.int/nutgrowthdb/2018jme-brochure.pdf?ua $=1$

8. Shekar M, Kakietek J, Dayton Eberwein J, Walters D. An Investment Framework for Nutrition: Reaching the Global Targets for Stunting, Anemia, Breastfeeding, and Wasting. 2017;1-8. Available from: http://elibrary.worldbank.org/ doi/book/10.1596/978-1-4648-1010-7

9. Bhutta ZA, Ahmed T, Black RE, Cousens S, Dewey K, Giugliani E, et al. What works ? Interventions formaternal and child undernutrition and survival. Lancet. 2008;371:471-440.

10. WHO. The double burden of Malnutrition, Policy Brief. Who/Nmh/Nhd/173. 2017;21(4):402-4.

11. Victora CG, de Onis M, Hallal PC, Blössner M, Shrimpton R. Worldwide timing of growth faltering: revisiting implications for interventions. Pediatrics [Internet]. 2010 Mar 1 [cited 2019 Jan 24];125(3):e473-80. Available from: http://www. ncbi.nlm.nih.gov/pubmed/20156903

12. Aguayo VM, Nair R, Badgaiyan N, Krishna V. Determinants of stunting and poor linear growth in children under 2 years of age in India: An in-depth analysis of Maharashtra's comprehensive nutrition survey. Matern Child Nutr. 2016;12:121-40.

13. World Health Organization. Childhood Stunting : Challenges and Opportunities. WHO Geneva. 2013;

14. Semba RD, de Pee S, Sun K, Sari M, Akhter N, Bloem MW. Effect of parental formal education on risk of child stunting in Indonesia and Bangladesh: a cross-sectional study. Lancet. 2008;371(9609):322-8.

15. Lee J, Houser RF, Must A, De Fulladolsa PP, Bermudez OI. Socioeconomic disparities and the familial coexistence of child stunting and maternal overweight in guatemala. Econ Hum Biol. 2012;10(3):232-41.

16. Schrijner S. Grandparents and Children 's WellBeing in sub-Saharan Africa : 2017.

17. Akseer N, Bhatti Z, Mashal T, Soofi S, Moineddin 
$\mathrm{R}$, Black RE, et al. Geospatial inequalities and determinants of nutritional status among women and children in Afghanistan: an observational study. Lancet Glob Heal. 2018;6(4):e447-59.

18. Ortiz J, Camp J Van, Wijaya S, Donoso S. Determinants of child malnutrition in rural and urban Ecuadorian highlands Determinants of child malnutrition in rural and urban Ecuadorian highlands. 2013;(September).

19. Chirande L, Charwe D, Mbwana H, Victor $\mathrm{R}$, Kimboka S, Issaka AI, et al. Determinants of stunting and severe stunting among underfives in Tanzania: Evidence from the 2010 cross-sectional household survey. BMC Pediatr [Internet]. 2015;15(1). Available from: http:// dx.doi.org/10.1186/s12887-015-0482-9.

20. Nkurunziza S, Meessen B, Van geertruyden JP, Korachais C. Determinants of stunting and severe stunting among Burundian children aged 6-23 months: Evidence from a national crosssectional household survey, 2014. BMC Pediatr. 2017;17(1):1-14

21. Israel P, Lira C De, Cristina S, Souza LA De. Determinant of Stunting in Children under Five in Pernambuco, Northeastern, Brasil. 2011;45(6).

22. Rahman N, Napirah MR, Nadila D, Bohari. Determinants of stunting among children in urban families in palu, Indonesia. Pakistan J Nutr. 2017;16(November):750-6.

23. Seedhom AE, Mohamed ES, Mahfouz EM. Determinants of stunting among preschool. Int Public Heal Forum [Internet]. 2014;1(2):6-9. Available from: http://www.researchpub.org/ journal/iphf/iphf.html.

24. Biswas S, Bose K. Sex differences in the effect of birth order and parents' educational status on stunting: A study on Bengalee preschool children from eastern India. HOMO- J Comp Hum Biol. 2010;61(4):271-6.

25. Abeway S, Gebremichael B, Murugan R, Assefa M, Adinew YM. Stunting and its determinants among children aged 6-59 Months in Northern Ethiopia: A cross-sectional study. J Nutr Metab. 2018;2018.

26. Schrijner S, Smits J. Grandparents and Children's stunting in sub-Saharan Africa. Soc Sci Med. 2018;205(October 2017):90-8.

27. WHO. Complementary Feeding of Young Children in Developing Countries : a Riview of Current Scientific Knowledge [Internet]. WHO; 1998. Available from: https://apps.who.int/iris/ handle/10665/65932

28. Reyes H, Pérez-cuevas R, Sandoval A, Castillo R, Santos JI, Doubova S V, et al. The family as a determinant of stunting in children living in conditions of extreme poverty : a case-control study. 2004;10:1-10.

29. UNICEF. Malnutrition in Children - UNICEF DATA [Internet]. UNICEF. 2018 [cited 2019 Feb 2]. Available from: https://data.unicef.org/topic/ nutrition/malnutrition/

30. Keino S, Plasqui G, Ettyang G, Van Den Borne B. Determinants of stunting and overweight among young children and adolescents in sub-Saharan Africa. Food Nutr Bull. 2014;35(2):167-78.

31. Zottarelli LK, Sunil TS, Rajaram S. Influence of parental and socioeconomic factors on stunting in children under 5 years in Egypt. East Mediteranean Heal J. 2007;13(6).

32. Strassmann BI. Cooperation and competition in a cliff-dwelling people. Proc Natl Acad Sci. 2011;108(Supplement_2):10894-901. 